\title{
Application of Rukhsah Solat by Malaysian Health Care Workers
}

\author{
Ahmad Faidhi M.Z. ${ }^{1}$, Basri, I. ${ }^{2}$
}

${ }^{1}$ Universiti Islam Malaysia, Cyberjaya, Malaysia / Hospital Angkatan Tentera Tuanku Mizan, Kuala Lumpur, Malaysia;

${ }^{2}$ Universiti Islam Malaysia, Cyberjaya, Malaysia / Faculty of Islamic Contemporary Studies, Universiti Sultan Zainal Abidin, Terengganu, Malaysia

\begin{abstract}
Introduction: Solat (Islamic prayer) is a mandatory act of worship to be performed by Muslim doctors albeit time constraint and dire condition while treating or resuscitating critical patients. Islam has allowed leniency (rukhsah) for such group to fulfill this obligation while executing their responsibility in saving life. This study aims to analyze current practice of rukhsah solat by Muslim health care workers (HCWs) during their critical call of duty.
\end{abstract}

Methods: This is a qualitative study. Document analysis from Islamic jurisprudence (fiqh) references and interviews with expert from both Islamic scholars and clinicians was conducted. Field observation was done to ascertain the practice among HCWs.

Results: The study identifies a few indication and reasons for HCWs to apply rukhsah solat, which are determined by their scope and place of duty as well as critical situation of patients. Those who are assigned for prolong operation or taking charge of intensive care unit, emergency and trauma department and labour rooms tend to practice rukhsah solat while on duty. Among types of rukhsah solat performed by HCWs are combining solat (jamak) and replacing solat outside the prayer time $\left(q a d a^{\prime}\right)$ once they finish the critical task or operation.

Conclusion: This study also analyzes current practice of rukhsah solat by HCWs in the light of Islamic jurisprudence (figh), hence suggesting recommendation to facilitate such practice to be more bearable among HCWs in accordance to the Objective of Syariah (Maqasid Syariah) and Islamic legal maxim (Qawaid Fiqhiyyah). 